\title{
Transition of Rights Ownership over Land Based on Absolute Power of Attorney (A Study of Civil Case Number 90/PDT.G/2013/PN.PDG)
}

\author{
Aprina Wardhani; Ferdi; Muhammad Hasbi \\ Andalas University, Indonesia
}

http://dx.doi.org/10.18415/ijmmu.v6i4.943

\begin{abstract}
Based on Article 39 paragraph (1) letter d PP No. 24 of 1997 stated that "PPAT refused to make a deed if one of the parties or parties acted on the basis of an absolute power of attorney which essentially contained the legal act of transferring rights" .In case number 90 / PDT.G / 2013 / PN.PDG between Bahar and Henky Sutanto CS, Hj. Elly Satria, S.H, H. Hendri Final, S.H, and the Land Agency of the City of Padang. The problem occurred because the power deed number 67 dated February 17, 1996 which was categorized as absolute power was made as the basis for the transfer of certified land rights without being preceded by the PPJB or any agreement, even though the Principal Agreement and this power cannot be separated. The formulation of the problem discussed in this thesis is how the process of transferring land rights is based on absolute power, how the legal consequences of transferring land rights are based on absolute power and how the responsibility of Notary / PPAT in making deeds that use absolute power as the basis of transfer of rights. The research method used is normative legal research. Based on what was investigated, the process of transferring land rights based on absolute power was carried out based on the usual judicial process, namely because the mediation failed, followed by the reading of the lawsuit, the respondent's reply, replication and duplication, verification, and the verdict was partially granted.The legal consequences with the use of absolute power in the case of transfer of ownership rights to land in this case resulted in the absolute deed of power being null and void. Based on the theory of accountability, the author argues that PPAT is responsible for making sale and purchase deeds based on absolute power. Losses to the parties for negligence of the PPAT are borne by the Official who, because of the negligence, has caused a loss.
\end{abstract}

Keywords: Transfer of Rights Ownership over Land; Absolute Power of Attorney; Notary / The Land Deed Official (PPAT)

\section{Introduction}

Land is part of the earth called the surface of the earth. Land is one of the objects regulated by agrarian law. Land that is regulated by agrarian law is not land in its various aspects, but land from its juridical aspect which is directly related to land rights which are part of the earth's surface as stipulated in Article 4 paragraph (1) of Law Number 5 of 1960 concerning Regulations Basic Agrarian Principles (hereinafter referred to as UUPA) which determine: on the basis of the controlling rights of the State as 
referred to in Article 2, there are various types of rights on the surface of the earth, which can be given to and can be owned by good people themselves and together with other people and legal entities.

Transfer of rights is a legal act that transfers land rights to another party. Transfer of rights is carried out if the legal status of the right to control the land meets the requirements as the holder of available land rights, and the holder of the right to the land is willing to transfer his rights. Legal actions to transfer rights can be in the form of buying and selling, exchanges, grants, wills and income / inbreng, where the legal action is based on Government Regulation No. 37 of 1998 concerning Land Deed Making Officer (PPAT) and is carried out before PPAT, then registered at the local Land Office.

Registration of land rights is an obligation of the government to provide legal certainty, especially for holders of land rights in all regions of Indonesia. This is in accordance with the mandate contained in the Basic Agrarian Law (UUPA) hereinafter abbreviated as UUPA, specifically Article 19 of the LoGA. This was then followed up in the implementing regulations, namely the Republic of Indonesia Government Regulation Number 24 of 1997 concerning Land Registration (hereinafter abbreviated as PP No. 24 of 1997). Land registration is intended not only for legal subjects that have not been registered at the land office, but also in the case of transfer of land rights transferred to someone or other legal entity.

In the case of carrying out a legal act for the transfer or transfer of a land right, it must be carried out before a Notary or Land Deed Officer (hereinafter abbreviated as PPAT) which aims to obtain a valid proof power and is made with an authentic deed. Particularly for lands that are certified as buying and selling or transferring rights are carried out before PPAT, but there are times when the sale and purchase is carried out before a notary, called a Sale and Purchase Agreement.

Although it may seem trivial, a power letter is just a piece of paper or a piece of paper, its impact is relatively large in handling matters. Article 1792 of the Penal Code states that "Authorization is an agreement by which one gives power to another, who accepts it in his name to carry out an affair". According to the nature of the agreement, the authorization can be either general or special. Pursuant to Article 1795 of the Civil Code referred to as special authorization is the authorization of only one or more particular interests, which means to perform certain acts, requiring special authorization which specifies acts to be done. General empowerment is the formulation of authority formulated in general terms, only covering management actions.

Normally, based on Article 39 paragraph (1) letter d PP No. 24 of 1997 states that "PPAT refuses to make an act when either party or the parties act on the basis of an absolute power of attorney which in effect constitutes a transfer of rights". As well as in Chapter VIII Article 62 PP No. 24 of 1997 governing sanctions states that:

"The PPAT in carrying out its duty disregards the provisions of Article 38, Article 39 and Article 40 as well as the provisions and instructions provided by the Minister or Officers appointed to administer administrative action in writing to the termination of his office as PPAT, without minimizing the possibility of reimbursement. damages by the parties suffering losses resulting from their neglect of these provisions".

Self-empowerment is not regulated in the Criminal Code, but is recognized in the business world of society. Absolute empowerment is an alliance arising from the treaty, which is governed by Article 1338 of the Civil Code, which recognizes the existence of contractual freedom. The limitation is that the agreement should not conflict with the rules of the law and must be in good faith. 
Against the prohibition on absolute power as set forth in Instruction of the Minister of Home Affairs No. 14 of 1982 on the Prohibition of the Use of Absolute Power as Transfer of Land Rights (hereinafter Abbreviated Directive No. 14 of 1982). The contents of these instructions include instructing all Governors of the Head of Regional Level I and Regents / Mayor of the Head of Regional Levels throughout Indonesia to prohibit the Head and Village Chief or the corresponding Officers, to make / enforce the production of the Permanent Authority which is essentially transfer of land rights. This directive also prohibits Agraria officials from serving on land rights settlement using absolute power of attorney as proof of transfer of land rights.

It should be noted that the prohibition on the exercise of absolute power as a transfer of land in question is a "non-compliant" authorization agreement. Where this is stated in the letter of the Director General of Agraria on behalf of the Interior Minister of the Republic of Indonesia. 594/493 / AGR, March $31,1982$.

In view of the provisions contained in the Letter of the Director General of Agraria on behalf of the Interior Minister of the Republic of Indonesia Normor 594/493 / AGR, it is stated that there are some uses of the excluded or excluded powers which are expressly prohibited by the use of the Directive Directive No. 14 of 1982, such as the exercise of full powers as specified in the Notarized Sale and Purchase Agreement (PPJB), the exercise of the absolute power to install an actual mortgage made by a notary and the exercise of other absolute powers not intended as transfer of rights on the ground.

In case number 90 / PDT.G / 2013 / PN.PDG between Bahar with Henky Sutanto CS, Hj. Elly Satria, S.H, H. Hendri Final, S.H, and Padang City Land Agency. In this case is Bahar who was the successor to the successor of the former heiress Alm Wahab, who during his lifetime passed away. Wahab has a grant of a high inheritance of his people with a land area of 41,842 M2 registered on 3 (three) certificates of ownership in the name of Wahab as the heir of his heirs and members: 1. Bahar 2. Rasani 3. Raja'i, address on the street Bypass Km 16,5 RT 02 / RW06. Koto Panjang Ikur Koto, Koto Tangah District, Padang City. That on February 17, 1996 at the persuasion of a person, Wahab Cs made power over Hendrino (defendant II), Syahwin Nikelas (defendant III) by Authorization Number 67 on February 17, 1996 and was not preceded by any agreement. Armed with this absolute power of indictment II and defendant III had sold the lands of Wahab Cs by first issuing his certificates. This would have been detrimental to the plaintiff and his people. In his judgment the judge stated that the warrant was revoked and sentenced the defendant to rescind the sale and sale act on the object and was later sentenced to surrender the land and buildings he owned in the free state of his and others' rights.

Based on the above description, there is a conflict between das sollen (which is or should be lawful) and das sein (which occurs or in fact), the CID should ideally refuse to make an act when either party or parties act on the basis of an absolute power of attorney. which in fact constitutes an act of transfer of rights. In fact, some PPATs do not object to the enactment of the Sale and Purchase Act despite the fact that one or the other parties are pursuing the Sale and Purchase Act using an absolute power of law which is in fact prohibited and would pose a great risk to both parties.

In view of the above issues, it is a personal appeal to the author to examine the issue under the heading: "Transfer of Land Rights Under the Absolute Power (Civil Case Study Number 90 / Rev.G / 2013 / PN.PDG)" 


\section{Formulation of the Problem}

Based on the background of the problems outlined above, then the center of attention of the authors in this study can be formulated the problem as follows: How is the process of the case of transfer of property based on absolute power?

\section{Research Methods}

The method used in this study is a normative juridical method, namely legal research conducted by examining library materials or mere secondary data. This research is carried out by testing and examining logically the rules relating to absolute power. The normative juridical approach is carried out on laws and regulations relating to absolute power which is then carried out at the level of synchronization both vertically and horizontally.

\section{Research Results and Discussion}

The process of the case for transfer of ownership rights is based on absolute power in civil cases number 90 / Pdt.G / 2013 / PN. PDG?

Based on research on the directory of decisions that have been decided in the Padang District Court in 2018 until May 2019, out of 256 decisions in 2018 and 141 decisions from January 2019 to May 2019, there has not been a single decision regarding unlawful acts concerning use of absolute power. The process of transferring ownership rights in this case is:

The Padang District Court examined and tried the civil lawsuit between:

BAHAR, As Mamak Head of Heirs in the Koto Tribe replaces Mamak The old Chief of Waris namely WAHAB who has passed away, Tani's work, resides in Sungai Lareh RT 007 RW 002 Lubuk Minturun Subdistrict, Koto Tangah District Padang, which in this case authorizes JUANDA RASUL, SH having his address at Jalan Maang No. 38 Padang, hereinafter referred to as CLAIMANT.

\section{AGAIN:}

HENKY SUTANTO, private work, residing on Jalan Kali kecil I No. 13 RT 03 RW 01 Padang Barat District, which in this case gave his power to H. CHAIDIR GANI, S.H., DONNY INDRA, S.H., L.LM, IRWAN ILYAS, S.H. Having his address at Jalan Andam Dewi No. 20 Padang, hereinafter referred to as ACCUSED I;

Ir. HENDRINO, private work, resides on Lombok street Blok F No. 17 Wisma Indah I Ulak Karang Padang, which in this case gave his power to H. CHAIDIR GANI, S.H., DONNY INDRA, S.H., L.LM, IRWAN ILYAS, S.H. Having his address at Jalan Andam Dewi No. 20 Padang, hereinafter referred to as ACCUSED II;

Drs. SYAHWIN NIKELAS, Lecturer work, residing on Semangka Blok K. No. 4 Wisma Indah II RT 003 RW 001 Nanggalo Padang District, which in this case gave his power to H. CHAIDIR GANI, S.H., DONNY INDRA, S.H., L.LM, IRWAN ILYAS, S.H. Having his address at Jalan Andam Dewi No. 20 Padang, hereinafter referred to as ACCUSED III; 
Hj. ELLY SATRIA, S.H. The official Land Deed Maker (PPAT), having his address at Jalan Ciliung Number 1 Padang Baru Timur City of Padang, hereinafter referred to as ACCUSED IV;

H. HENDRI FINAL, S.H. Acting Land Deed Maker (PPAT), having his address at Jalan Veteran Number 9 Padang, hereinafter referred to as ACCUSED V;

Government of the Republic of Indonesia Cq National Land Agency of the Republic of Indonesia $\mathrm{Cq}$ Land Agency of West Sumatra Province Cq Padang City National Land Agency, having the address at Ujung Gurun street Number 1 Kota Padang, hereinafter referred to as ACCUSED VI.

This case originated from the following, namely Bahar, who was the Head of the Waris (hereinafter abbreviated as MKW), a substitute for the previous MKW named al-Wahab. 02 / RW 06 Koto Panjang Ikur Koto Village, Koto Tangah District, Padang City. Wahab cs is the party authorized to control the land which can be proven based on case number 170 / Pdt.G / 1993 / PN. In the dispute between Uyun cs and Wahab cs and won by Wahab cs that the land belonged to the Lamban Tribe of the Koto Tribe namely Wahab cs based on the decision of the Republic of Indonesia Supreme Court Reg. No. 3201 K / Pdt / 1995 and was executed by the Padang District Court based on the Minutes of Implementation of Decision No. 170 / Pdt.G / 1993 / Pn.Pdg. The certificate of the three land disputes is known as certificates:

a. Property Certificate Number 629 located in Koto Panjang Ikur Koto Subdistrict, Koto Tangah District, Padang City having its address at Km 16.5 Bypass Road RT 02 / RW 06, Figure situation Number 43, Area 22,650 M2 on September 2, 1991 in the name of Wahab as MKW and members of his people are named: 1. Bahar, 2 Rasani, 3. Raja'i;

b. Property Certificate Number 887 located in Koto Panjang Ikur Koto Village, Koto Tangah District, Padang City having its address at Km 16.5 Bypass Road RT 02 / RW 06, Figure situation Number 595, Area 3192 M2 dated March 16, 1993 in the name of Wahab as MKW and members of his people are named: 1. Bahar, 2 Rasani, 3. Raja'i;

c. Property Certificate Number 888 located in Koto Panjang Ikur Koto Subdistrict, Koto Tangah District, Padang City having its address at Km 16.5 Bypass Road RT 02 / RW 06, Picture situation Number 195, Area 16,000 M2 dated January 26, 1994 in the name of Wahab as MKW and members of his people are named: 1. Bahar, 2 Rasani, 3. Raja'i;

That on February 17, 1996 at the persuasion of someone and with the pretext of deceiving and with an irrational promise and trust from the village people to the educated, the late Wahab as the MKW was brought before the PPAT a power of attorney was made to Defendant II, III and Mr Azri Satya made before Amril Notary substitute Hendri Final, SH Armed with this power of attorney, the party receiving the power of attorney, namely Defendant II and Defendant III had:

1. Sell land ownership certificate number 629 to Henky Susanto / Defendant I as the buyer with the Buy and Sell Deed No. 447/658 / K.Tangah / 2001 dated September 8, 2001 and then reversed the name of the buyer Henky Sutanto / Defendant I before Eli Satria / defendant IV as PPAT;

2. Reversing the name of land ownership certificate number 887 to Syahwin Nikelas / Defendant III with the Buy and Sell Deed No. 834 / KT / JB / 2001 dated May 22, 2001 before Hendri Final / defendant $\mathrm{V}$ as PPAT;

3. Turn the name of the land ownership certificate number 888 to Hendrino / Defendant II with the Buy and Sell Deed No. 833 / KT / JB-2001 dated May 22, 2001 before Hendri Final / defendant V as PPAT; 
Furthermore, the Plaintiff has gone through an administrative process, namely the process of filing and registering cases where this case was registered on May 31, 2013 with case number 90 / Pdt.G / 2013 / Pn.Pdg, after which the proceedings began.

\section{Decision}

In the exception, considering that the power of Defendants I, II and III explained the plaintiff's claim Nebis in Idem, that between cases number 72 / Pdt.G / 2008 / PN. PDG with case number 90 / Pdt.G / 2013 / Pn. Pdg there is a difference between the parties of the plaintiff and the defendants, because there is no similarity as stated in Article 1917 BW, namely Nebis in Idem that occurs if the claim is based on the same reason, submitted by and against the same person and in the same relationship, so that the Nebis In Idem is unwarranted. Considering furthermore that the object of the case in the form of land argued by the defendant belongs to his / her property as stated in his exception is declared rejected because it is included in the subject matter. Considering the exception related to the change in claim, the change in the claim can be justified because the defendant was present in the trial which in the judicial practice in Indonesia changes to the lawsuit were permitted provided that it was submitted on the day of the first trial in which the parties attended.

In the case of the case, it was related that Bahar was the previous MKW MKW substitute as evidenced by the P-13 proof letter in the lineage of the Koto Lambam Tribe of the Lambs made by Bahar as MKW in his folk and known by the Minangkabau (KAN) Kerapatan Adat Koto Tangah, The Head of the Koto and Ninik Mamak Tribes of the Koto Tribe and other relevant evidence can be proven that Bahar is the MKW substitute for the previous MKW.

Whereas in this case it was revealed that there was a sale and purchase authority with deed no. 67 dated February 17, 1996 as stated in the proof letter marked P-5, in the form of giving of absolute power from Wahab cs to Syahwin Nikelas Cs to sell land that has been certified, so that it is contrary to the Instruction of Minister of Home Affairs No. 14 of 1982, because the purpose of the prohibition included in the consideration of letter $\mathrm{C}$, namely to avoid legal abuse and covert transfer of land rights, this is very relevant to the plaintiffs' arguments stating that Wahab cs was persuaded to make a power of attorney against Defendant II and Defendant III and Br. Azri Satya before Amril Notary Substitute from Hendri Final, S.H.

This case was decided on April 24, 2014 with a ruling:

In the exception: reject the Defendant I, II and III exceptions for the whole;

In the subject matter:

1. To grant the claim of the plaintiff in part;

2. To declare that the legitimate plaintiff named Bahar is the MKW substitute for the previous MKW, the late Wahab;

3. Declare the legal title of Property Ownership number: 629 with picture situation number 3243, area of 22,650 M2, and Certificate of Property Number: 887 image situation number 595, area of 3192 M2, and certificate of Property Number 888 image situation number 195, area 16,000 located on Km 16.5 Bypass RT 02 / RW 06 Koto Panjang Ikur Koto Subdistrict Koto Tangah Subdistrict, Padang City is legal according to the plaintiff's law and the defendant's actions as the power of attorney and the 
competent authority issues the power of attorney and reverses the certificates, including selling it is illegal and is very detrimental to the plaintiff and his people;

4. Declare null and void the letter registered at the Defendant's office, namely Deed No. 67 dated 17 February 1996 made by Defendant IV as Acting Land Deed Officer;

5. Declaring the Acts of Defendant II Hendrino and Defendant III Syahwin Nikelas were acts against the law which were very detrimental to the plaintiff and his people;

6. Sentencing Defendant II Hendrino and Defendant III Syahwin Nikelas to submit the certificate of ownership of the Plaintiff as the rightfully entitled to the Plaintiff and if Defendant I, Defendant II and Defendant III would not be forced to do so by the Padang District Court with the assistance of the authorities ;

7. Sentencing Defendant I Henky Susanto to cancel the sale and purchase deed to Defendant II Hendrino and Defendant III Syahwin Nikelas for the object of the case and then sentenced to surrender the land and buildings it controls in an empty condition free of his rights and the rights of others who have the right to him, if Defendants I, II, and III do not want to be made a forced effort by the Court with the help of the legal authorities;

8. Declare legal and valuable seizure guarantees against the object of the case in the form of land;

9. Punish the defendant to pay the court fees that arise in this case.

Later, on May 2, 2014 the defendant appealed the decision of the case. 90 / Rev.G / 2013 / Pn. Pdg, with civil appeal list No. 127 / Pdt / 2014 / PT. The matter was decided on September 11, 2014 with the verdict of ordering the case to be dropped on issue number 127 / Rev. / 2014 / PT.Pdg of the civil case register as the appellant dismissed his appeal.

In the case of absolute empowerment here the judge's consideration is that the development of the law of a treaty whether it is a sale or non-sale agreement, has been recognized in the contract of liberty in accordance with the provisions of Article 1338 of the Constitution. The developed contractual freedom, too, includes absolute empowerment. However, the enforcement of the contractual terms of freedom including the authorization agreement cannot be contrary to the rules of the law.

Considering that in this case the existence of the sale and sale of the deed of no. 67 dated February 17, 1996 as stated in evidence marked P-5, the contents of which are expressly authorized from Wahab Cs to Drs. Syahwin Nikelas Cs for the sale of certified land, thus clearly contrary to Dedication Instructions No. 14 In 1982, as the intent of the prohibition was included in the letter C's intent, to prevent misuse of law and relinquishment of land rights, this was particularly relevant to the plaintiff's main argument that Wahab Cs was persuaded to file a lawsuit against Defendant II. and Defendant III and to Sdr. Azri Sarya before Amril Notary Substitute from Hendri Final, S.H.

Considering that, due to the sale and sale authorization under Act No. 67 dated February 17, 1996 as stated in the P-5 affidavit containing the grant of absolute authority from Wahab Cs to Drs Syahwin Nikelas Cs for sale of certified land, has been expressly contrary to the Directive Directive No. 14 In 1982, the acts received by the assignee were to be declared lawful by the whole process of repatriation and sale and sale of certified land called Certificate of Title No. 629 on behalf of Defendant I, and Certificate of Title No. 888 on behalf of Defendant II, and Certificate of Title 887 In Defendant III's name, must be declared void by law. 
In this case the cause of action against the law is:

a. The making of an unauthorized power of attorney is based on persuasion. Where in this case on February 17, 1996, a person was persuaded to have Wahab cs take power over Hendrino (defendant II), Syahwin Nikelas (defendant III), and Sdr Azri Sarya before the Land Acting Officer Amril Notary of Hendri Final, SH, the warrant was made;

b. According to the instructions of the Home Minister 14/1982 of March 06, 1982 concerning the Prohibition of the Use of Absolute Power in the Transfer of Land Rights, where the rule does not permit the use of an absolute power in the case of a transfer of land which the 67th of February 17, 1996 constituted an absolute grant of Wahab cs to Syahwin Nikelas cs to sell certified land.

In decree No. 67 of February 17, 1996 it is known in the warrant that Wahab cs authorizes Syahwin Nikelas cs to represent the authorization to sell and / or otherwise transfer in whole or in part, at all prices and terms which by the consignee is weighed well on anyone who includes himself / herself in the 3 parcels of the land. Then also receives the proceeds of the sale and receives the receipt for the sale, submits what is sold to the buyer and then proceeds when necessary, including before PPAT or Notary anywhere, giving evidence, reporting, making, ordering signing and submitting other acts and papers, choosing his temporary residence to do and doing whatever is necessary, nothing is excluded. That the consignee must hold such power to the donor.

In the second dictation of the Order of Divorce No. 14 of 1982 is about the type of absolute power prohibited for use in the transfer of land rights. From the contents of the second dictation it can be concluded that the absolute prohibited power is a power that has 3 (three) elements:

1. The object of that power is land;

2. The power of attorney contains an irrevocable element by the authorizer and;

3. The power of attorney gives authority to the power of attorney to control and use the land and carry out all legal actions which according to the law can only be carried out by the rights holder, and in essence constitute a transfer of land rights.

In the deed of power number 67 dated February 17, 1996 above does not include the classul cannot be revoked, but fulfilling the object elements of the power is land and the element gives authority to the recipient of the power to control and use the land and carry out all legal actions carried out by the rights holders, and essentially constitutes a transfer of land rights. So that this power deed is categorized as absolute power.

The absolute power clause is not always prohibited from using it. In the practice of notary, the notary often includes an absolute power clause in the deed made. The granting of absolute power which is a clause in the deed that can be made notariil can be provided with the following conditions:

1. The existence of a principal agreement;

2. The authorizing rights have been fulfilled;

3. The original parties may not be substituted with other parties;

4. Is a part not separate from the main agreement.

Notariil absolute power in practice there are those who use the title "agreement / bond of sale and purchase" or "power to sell". As explained above regarding the relationship between agreements and 
agreements is that the agreement is the source of the engagement (legal relationship). The agreement of the parties is the initial stage of the formation of buying and selling. The intention is to make a sale and purchase agreement, including:

1.The certificate has not been issued / made on behalf of the seller, and is still in process at the Land Office;

2. The certificate is not on behalf of the seller, and is still in the process of returning the name to the name of the seller;

3. The certificate already exists and is already on behalf of the seller, but the agreed purchase price has not all been paid by the buyer to the seller;

4. The certificate already exists, already on behalf of the seller and the price has been paid in full by the buyer to the seller, but the requirements are not complete;

5. Certificates have been used as collateral in the bank and have not been carried out yet.

Looking at the reasons mentioned above, then to secure the interests of the seller and the buyer from the possibility of things that are not desirable, for example, there are broken promises from the parties, there needs to be a handle or guideline. At the absolute power that is prioritized is the interests of the buyer, because in the absolute power of notariil the seller gives a broad and irrevocable power, which is absolute, which by the power of attorney can take all legal actions and actions regarding the land concerned, all of which can be carried out by the author of his own authority as the owner.

The power to sell is included in the category of special power that is used to transfer objects that can only be done by the owner. Therefore, for the power to sell, a power of attorney is required with clear words in the deed (Article 1796 of the Civil Code).

The Deed of Bonding Sale and Purchase Agreement (hereinafter abbreviated as PPJB) and the power to sell it is also an inseparable partner. These two deeds are not contradictory, even complementary. This also means that the PPJB and the power to sell are a single entity. The power to sell in PPJB is to provide a guarantee or protection to the recipient of the power of attorney (buyer), after the conditions required in the sale and purchase of land are fulfilled, to be able to exercising the rights arising from the sale or signing of the AJB itself without the presence of the lender (seller) before the PPAT.

The power to sell the land will not be terminated by reason of the provisions of the Article 1813 of the Constitution which is the death of the executor or the executor. This is because the power of an accessory is in the nature of an accessory that is in compliance with its principal and non-exclusive agreements, which means that the granting of an absolute power clause is an indivisible right of its ultimate agreement and is therefore non-binding and irrevocable. This power of sale is intended to guarantee the exercise of the rights of the buyer who has paid the full price of the sale to the seller or for the benefit of the assignee and no longer has the seller's interest in the sale power. With the power of selling, in the signing of AJB the buyer no longer requires the seller's presence. Buyers legally represent the seller and represent themselves.

Unless the power of sale is made purely for the purpose of selling an asset without regard to the PPJB Act. The purely selling power may be revoked by a power withdrawal act, in the case of sale and return of the name has not been done. And this kind of power cancels itself when the grantor dies. 
Based on the above issues, the Act No. 67 of February 17, 1996 categorized as absolute power was used as the basis for transfer of certified land rights, without having been enacted by the NPA or any other treaty, but the Principal Agreement and this power were inseparable. This results in the act being unlawful because it is against the law. Illegal acts are governed by Article 1365 of the Civil Code which states:

"Every act that violates the law and carries a loss to another person, requires the person who caused the loss because of his mistake to replace the loss"

From the sound of the Article, then, the elements of unlawful acts can be drawn into existence of unlawful acts, of wrongdoing, of the causal relationship between loss and deed, and of loss. Illegal acts means that the acts or acts of the offender are not only limited to the written law (law) but also the unwritten law, namely:

1. Violation of the Law, which means that acts committed are clearly in violation of the law;

2. Violates the subjective rights of others, meaning that if the act is committed violates the rights of others that are guaranteed by law (including but not limited to personal rights, freedom, material rights, honor, good name or other individual rights;

3. Contrary to the legal obligations of the offender, meaning legal obligations both written and unwritten, including public law;

4. Contrary to the attitude of caution that is appropriate in society. This criterion is based on an unwritten law (relative). That is, the actions taken are contrary to the good attitude / propriety in the community to pay attention to the interests of others.

Associated with the criteria of buyers with good intentions, namely:

1. To buy and sell land objects with legal procedures / procedures and documents as determined by legislation, namely:

a. Land purchase through public auction, or;

b. Purchase of land in the presence of PPAT or;

c. Purchases of customary / unregistered land carried out according to the provisions of customary law, namely:

i. Performed in cash and light (in front of / known to the Head of the Village / Local Village);

ii. It is preceded by research on the status of the land of sale and purchase and based on the research shows that the land of sale and purchase is owned by the seller.

d. Purchases are made at a reasonable price;

2. Carry out caution by examining matters relating to the object of the land promised, including:

a. The seller is the person who has the right / ownership of the land that is the object of buying and selling, in accordance with the proof of ownership, or;

b. The land / object being traded is not confiscated, or;

c. For certified land, information from the BPN has been obtained and a history of the legal relationship between the land and the certificate holder.

regarding this criterion, the judge also assessed the criteria of goodwill buyers including: 
1. The judge believes that the buyer can be categorized as having good intentions, related to the sale and purchase of customary land or not yet registered, if it is carried out in accordance with the provisions of customary law, namely fulfilling the real, cash and bright elements;

2. The buyer is categorized as a good intention buyer, if the sale and purchase is carried out fulfilling the procedures as stipulated in the LoGA, and PP No. 24 of 1997. That is, if the sale and purchase of land is carried out before PPAT, and is registered at the land office;

3. Buyers can be considered goodwill, if buying and selling has been carried out with a reasonable process, for example reasonable prices and no conspiracy;

4. The obligation of the buyer to make sufficient efforts carefully and carefully inspect the land object before and during the sale and purchase. The prudence of the buyer is assessed by taking sides as to whether the buyer has ensured that the seller is the person who is truly entitled to the land to be sold, according to proof of ownership.

The method of making this power of attorney also does not reflect the good faith of the buyer as stated in the lawsuit, namely by persuading someone and with the pretext of deceiving and with irrational promises and the trust of the village people to the educated.

\section{Conclusion}

In civil matters 90 / Rev.G / 2013 / PN.The matter is due to the defendant using Act No. 67 of February 17, 1996 categorized as absolute authority as the basis for transferring certified land rights, without having been preceded by the PPJB or any agreement, This Agreement and the powers are inseparable. The act was also made by persuading the plaintiff to exercise that power. This results in the act being unlawful because it is against the law.

\section{References}

Book

Abdurachman, Masalah Pencabutan Hak dan Pembebanan Atas Tanah di Indonesia, Sari Hukum Agraria I, Alumni, Bandung, 2010.

Achmad Ali, Menguak Teori Hukum (Legal Theory) dan Teori Peradilan (Judicialprudence) Termasuk Interpretasi Undang-Undang, Kencana Prenada Media Group, Jakarta, 2009.

Adrian Sutedi, Peralihan Hak Atas Tanah Dan Pendaftarannya. Jakarta, Sinar Grafika.2009.

Amiruddin dan Zainal Asikin, Pengandar Metode Penelitian Hukum, RajaGrafindo Persada, Jakarta, 2003.

Boedi Harsono, Hukum Agraria Indonesia, Sejarah Pembentukan Undang-Undang Pokok Agraria, Isi dan Pelaksanaanya, Jilid 1 Hukum Tanah Nasional, Djambatan, Jakarta,1999.

Darwin Ginting, Hukum Kepemilikan Hak Atas Tanah Bidang Agribisnis, Bogor, Ghalia Indonesia, 2010. 
Efendi Perangin, Hukum Agraria di Indonesia, Suatu Telaah dari Sudut Pandang Praktisi Hukum, PT. RajaGrafindo Persada, Jakarta, 1994.

Erna Sri Wibawanti \&R. Murjiyanto, Hak Atas Tanah dan Peralihannya, Liberty,Yogyakarta,Liberty, 2013.

E.Y.Kanter dan S.R. Sianturi, Asas-Asas Hukum Pidana di Indonesia dan Penerapannya, Alumni AHMPTHM, Jakarta, 1982.

Herlien Budiono, Dasar Teknik Pembuatan Akta Notaris, Cetakan II, PT. Chitra Aditya Bhakti, Bandung, 2014.

Jayadi Setiabudi, Panduan lengkap Mengurus Tanah Rumah Serta Segala Perizinannya,Buku Pintar, Yogyakarta, 2013.

J. Satrio, Hukum Perjanjian, Perjanjian Pada Umumnya, PT. Citra Aditya Bhakti, Bandung, 1992.

Komar Andasasmita, Notaris Selayang Pandang, Cet. 2, Alumni, Bandung.

L.J van Apeldoorn, Pengantar Ilmu Hukum, Pradnya Paramita, Jakarta, 2004.

M Syamsudin, Operasionalisasi Penelitian Hukum, Raja Grafindo Persada, Jakarta, 2007.

M. Yahya Harahap (a), Segi-Segi Hukum Perjanjian , cetakan ke 2, Alumni, Bandung, 1986 .

M. Yahya Harahap(b), Hukum Acara Perdata : Tentang Gugatan, Persidangan, Penyitaan, Pembuktian, dan Putusan Pengadilan, cet. ke-1, Sinar Grafika, Jakarta, 2005.

Philipus M. Hadjon, Kisi-kisi Hukum Administrasi dalam Konteks Tindak Pidana Korupsi, dalam Philipus M. Hadjon, dkk., Hukum Administrasi dan Tindak Pidana Korupsi, Gadjah Mada, 2012.

Peter Mahmud Marzuki, Pengantar Ilmu Hukum, Edisi Revisi, Kencana Prenada Media Group, Jakarta, 2012.

Purnadi Purbacaraka dan Soerjono Soekanto, Perihal Kaedah Hukum, Penerbit Alumni, Bandung, 1982.

Rachmad Setiawan, Hukum Perwakilan dan Kuasa Suatu Perbandingan Hukum Indonesia dan Hukum Belanda Saat Ini, PT. Tatanusa, Jakarta, 2005.

Ridwan, Tiga Dimensi Hukum Administrasi dan Peradilan Administrasi, FH UII Press, Yogyakarta, 2009.

Ridwan, Diskresi \& Tanggung Jawab Pemerintah, FH UII Press, Yogyakarta, 2014.

Ridwan HR, Hukum Administrasi Negara Edisi Revisi, RajaGrafindo Persada, Jakarta, 2014.

R. Subekti, Aneka Perjanjian, Alumni, Bandung, 1984.

R. Subekti, Aneka Perjanjian, Cet -11, PT. Citra Aditya Bhakti, Bandung 2014. 
Shidarta, Moralitas Profesi Hukum Suatu Tawaran Kerangka Berpikir, PT Refika Aditama, Bandung, 2006.

Sjaifurrahman dan Habib Adjie, Aspek Pertanggungjawaban Notaris dalam Pembuatan Akta, CV. Mandar Maju, Bandung, 2011.

Soerjono Soekanto, Pengatar Penelitian Hukum, UI-Press, Jakarta, 1982.

S.F. Marbun, Peradilan Administrasi Negara dan Upaya Administratif di Indonesia, FH UII Press, 2015.

Soerjono Soekanto dan Sri Mamudji, Penelitian Hukum Normatif-Suatu Tinjauan Singkat, PT

RajaGrafindo Perkasa, Jakarta, 2006.

Salim HS dan Erlies Septiana Nurbaini, Penerapan Teori Hukum Pada Penelitian Tesis dan Disertasi, RajaGrafindo Persada, Jakarta, 2013.

Subekti, Hukum Perjanjian, cetakan ke 12, PT. Intermasa, Jakarta, 1990.

Theo Huijbers, Filsafat Hukum dalam Lintas Sejarah, Penerbit Kanisius, Yogyakarta, 1982.

Urip Santoso, Pendaftaran dan Peralihan Hak Atas Tanah, Kencana Prenadamedia Group, Jakarta, 2010.

Urip Santoso, Hukum Agraria Kajian Komprehensif, Kencana Prenadamedia Group, Jakarta, 2012.

Urip Santoso, Perolehan Hak Atas Tanah, Prenadamedia Group, Jakarta, 2015.

Wirjono Prodjodikoro, Hukum Perdata tentang Persetujuan-Persetujuan Tertentu, Sumur Bandung, Bandung, 1981.

Yopie Morya Immanuel Patiro, Diskresi Pejabat Publik dan Tindak Pidana Korupsi, Keni Media, Bandung, 2012.

Zainuddin Ali, Metode Penelitian Hukum, Sinar Grafika, Jakarta, 2011.

\section{Regulations}

Kitab Undang-Undang Hukum Perdata (Burgerlijk Wetboek), diterjemahkan oleh, R. Subekti dan R. Tjitrosudibio, cet ke-28, Pradya Paranuta, Jakarta, 1996.

Undang - Undang Nomor 5 Tahun 1960 Tentang Peraturan Dasar Pokok-Pokok Agraria.

Undang-Undang Nomor 2 Tahun 2014 Tentang Perubahan Undang-Undang Nomor 30 Tahun 2004 Tentang Jabatan Notaris.

Undang-Undang Nomor 37 Tahun 2008 Tentang Ombudsman Republik Indonesia, Lembaran Negara RI Tahun 2008 Nomor 139 dan Tambahan Lembaran Negara RI Nomor 4899.

Peraturan Pemerintah Nomor 24 Tahun 1997 Tentang Pendaftaran Tanah;

Peraturan Pemerintah Nomor 24 Tahun 2016 Tentang Perubahan Atas Peraturan Pemerintah Nomor 37 Tahun 1998 Tentang Peraturan Jabatan Pejabat Pembuat Akta Tanah (PPAT); 
Instruksi Menteri Dalam Negeri Nomor 14 Tahun 1982 tentang Larangan Penggunaan Surat Kuasa Mutlak Sebagai Pemindahan Hak Atas Tanah;

Surat Direktur Jenderal Agraria atas nama Menteri Dalam Negeri Republik Indonesia Nomor 594/493/AGR tanggal 31 Maret 1982 tentang Pelarangan Pengesahan Akta Kuasa Mutlak yang Menyangkut Tanah.

Journal, Tesis

Hayatin Nufus "Tanggung Jawab Notaris/PPAT Dalam Proses Balik Nama Sertifikat Hak Milik Atas Tanah" Tesis Magister Kenotariatan Fakultas Hukum Universitas Andalas, Padang, 2017.

Habib Adjie, Penegakan Etika Profesi Notaris dari Perspektif Pendekatan Sistem, Media Notariat, Edisi April-Juni, INI, Jakarta, 2002.

Nelly Sriwahyuni Siregar, Tinjauan Yuridis Kedudukan Kuasa Mutlak Dalam Peralihan Hak Ats Tanah Oleh Notaris/PPAT, Tesis Pada Program Pasca Sarjana USU Medan,2008.

Clara Vania, Keabsahan Penggunaan Kuasa Mutlak Dalam Perjanjian Pengikatan Jual Beli (PPJB) Tanah yang dibuat oleh Notaris, Jurnal Hukum Adigama, Fakultas Hukum Universitas Tarumanegara, diakses tanggal 1 Juni 2019, pukul 22.25 WIB

Sudarmono, "Balik Nama Sertipikat Hak Milik Berdasarkan Akta Jual Beli yang Menggunakan Kuasa Mutlak di Kota Pekanbaru", Tesis Pada Program Pascasarjana Magister Kenotariatan Fakultas Hukum Universitas Andalas, 2017.

Website

https://kbbi.web.id

www.definisimenurutparaahli.com.

Tata Wijayanta, Asas Kepastian Hukum, Keadilan dan Kemanfaatan dalam Kaitannya dengan Putusan Kepailitan Pengadilan Niaga, http://dinamikahukum.fh.unsoed.ac.id/index.php/JDH/article/viewFile/291/285,

https://iloveproperty.id/

www.pajak.go.id

http://kenalhukum.blogspot.com-surat-kuasa-mutlak.html,

\section{Copyrights}

Copyright for this article is retained by the author(s), with first publication rights granted to the journal. This is an open-access article distributed under the terms and conditions of the Creative Commons Attribution license (http://creativecommons.org/licenses/by/4.0/). 